\title{
Stress ulcer prophylaxis in intensive care unit patients receiving enteral nutrition: a systematic review and meta-analysis
}

\author{
Hui-Bin Huang ${ }^{1,2+}$, Wei Jiang ${ }^{1 \dagger}$, Chun-Yao Wang ${ }^{1}$, Han-Yu Qin ${ }^{1}$ and Bin Du ${ }^{1 *}$
}

\begin{abstract}
Background: Pharmacologic stress ulcer prophylaxis (SUP) is recommended in critically ill patients with high risk of stress-related gastrointestinal (Gl) bleeding. However, as to patients receiving enteral feeding, the preventive effect of SUP is not well-known. Therefore, we performed a meta-analysis of randomized controlled trials (RCTs) to evaluate the effect of pharmacologic SUP in enterally fed patients on stress-related Gl bleeding and other clinical outcomes.

Methods: We searched PubMed, Embase, and the Cochrane database from inception through 30 Sep 2017. Eligible trials were RCTs comparing pharmacologic SUP to either placebo or no prophylaxis in enterally fed patients in the ICU. Results were expressed as risk ratio (RR) and mean difference (MD) with accompanying 95\% confidence interval (CI). Heterogeneity, subgroup analysis, sensitivity analysis and publication bias were explored.

Results: Seven studies ( $n=889$ patients) were included. There was no statistically significant difference in $\mathrm{Gl}$ bleeding (RR 0.80; 95\% Cl, 0.49 to 1.31, $p=0.37$ ) between groups. This finding was confirmed by further subgroup analyses and sensitivity analysis. In addition, SUP had no effect on overall mortality (RR $1.21 ; 95 \% \mathrm{Cl}, 0.94$ to $1.56, p=0.14$ ), Clostridium difficile infection (RR $0.89 ; 95 \% \mathrm{Cl}, 0.25$ to $3.19, p=0.86$ ), length of stay in the ICU (MD 0.04 days; $95 \% \mathrm{Cl},-0.79$ to 0.87 , $p=0.92$ ), duration of mechanical ventilation ( $M D-0.38$ days; $95 \% \mathrm{Cl},-1.48$ to $0.72, p=0.50$ ), but was associated with an increased risk of hospital-acquired pneumonia (RR 1.53; $95 \% \mathrm{Cl}, 1.04$ to $2.27 ; p=0.03$ ).

Conclusions: Our results suggested that in patients receiving enteral feeding, pharmacologic SUP is not beneficial and combined interventions may even increase the risk of nosocomial pneumonia.
\end{abstract}

Keywords: Stress ulcer prophylaxis, Enteral nutrition, Critically ill, Meta-analysis

\section{Background}

Over the past decades, stress-related bleeding has become extremely uncommon in intensive care unit (ICU) patients [1]. Apart from pharmacologic approaches for stress ulcer prophylaxis (SUP), advances in the care of critically ill patients, such as optimal fluid resuscitation to maintain hemodynamic stability and thus improve splanchnic perfusion, and early provision of enteral nutrition (EN), may contribute to this observation [2-4]. Although recommended only in patients on mechanical ventilation or coagulopathy, patients with traumatic brain

\footnotetext{
*Correspondence: dubin98@gmail.com

${ }^{\dagger}$ Equal contributors

${ }^{1}$ Medical ICU, Peking Union Medical College Hospital, Peking Union Medical College and Chinese Academy of Medical Sciences, 1 Shuai Fu Yuan, Beijing 100730, People's Republic of China

Full list of author information is available at the end of the article
}

injury or major burns, or those with $\geq 2$ risk factors $[5,6]$, SUP is still being used in nearly $90 \%$ of ICU patients, despite lack of an accepted indication in the majority [79]. Furthermore, SUP is often continued in these patients until clinical improvement, or even after transfer to the general ward $[1,10]$. However, SUP is not without risks. The extensive use of SUP has been demonstrated to be associated with a higher rate of hospital-acquired pneumonia (HAP) due to loss of the protective bacteriostatic effect of gastric acid [4, 11]. Meanwhile, concomitant treatment of SUP and broad-spectrum antibiotics has also contributed to higher risks of Clostridium difficile infection [12, 13]. Thus, selection of potentially high-risk patients who may benefit from SUP while avoiding unnecessary use in others is important. 
Some earlier studies reported that EN alone might provide sufficient prophylaxis against stress-related gastrointestinal (GI) bleeding [3, 14]. In animal models, enteral feeding is documented to increase GI blood flow and provide protection against GI bleeding $[15,16]$. In a prospective, open-label trial, continuous EN was shown more likely than proton pump inhibitors (PPIs) or histamine 2 receptor antagonists $\left(\mathrm{H}_{2} \mathrm{RAs}\right)$ to raise gastric $\mathrm{pH}$ to above 3.5, suggesting that EN might be more effective in preventing GI bleeding than pharmacologic SUP [17]. Although several recent systematic reviews have comparatively evaluated pharmacologic agents for SUP, few of these studies have specialized in patients received EN [4, 18-20]. In 2010, one meta-analysis comparing $\mathrm{H}_{2}$ RAs to placebo or no prophylaxis for SUP looked into a subgroup of enterally fed patients. In this subgroup, SUP did not decrease the risk of bleeding, and in contrast led to more episodes of hospital-acquired pneumonia (HAP) and higher mortality rate [4]. However, these findings were based on an evaluation of only 262 patients in three randomized controlled trials (RCTs) (three trials in GI bleeding, two trials in HAP and mortality), which were published between the years 1985 and 1994 and compared $\mathrm{H}_{2} \mathrm{RAs}$ with placebo [21-23]. In addition, two out of the three RCTs were unblinded $[21,22]$, and some of potentially important outcomes to clinicians or patients, including duration of mechanical ventilation, incidence of $C$. difficile infection, ventilatorassociated pneumonia (VAP) and length of ICU stay were not considered in this meta-analysis.

Therefore, in order to address these limitations, we sought to expand the previous meta-analysis by adding relevant RCTs published between 1994 and 2017, and including any prophylaxis regimens. We reviewed these RCTs to determine if there are differences between pharmacologic SUP and placebo or no prophylaxis in enterally fed patients in terms of stress ulcer-related GI bleeding, and other clinical outcomes.

\section{Methods}

\section{Search strategy and selection criteria}

This systematic review and meta-analysis was conducted in accordance with the PRISMA guidance [24]. We searched RCTs in PubMed, Embase, and the Cochrane database from inception to 30 Sep 2017 to identify potentially relevant studies.

A population, intervention, comparator and outcomes assessment based on question and literature search was created (Additional file 1: S1). Our research was limited to RCTs and no language restriction was applied. Reference lists of included articles and other systematic review and meta-analysis were also reviewed. We included studies that met the following criteria: (1) design - RCTs; (2) population - adult ( $\geq 18$ years old) ICU patients receiving
EN; (3) intervention - patients receiving any pharmacologic SUP, regardless of dosage, frequency and duration; (4) control - patients receiving placebo or no prophylaxis; (5) predefined outcomes - GI bleeding, overall mortality at the longest available follow up, HAP, length of ICU stay, duration of mechanical ventilation and $C$. difficile infection. To facilitate comparison with the previous meta-analysis by Marik et al. [4], we required included studies to specifically report that $>50 \%$ of enrolled patients received EN [4]. We excluded studies enrolling patients who were $<18$ years old, using SUP due to active bleeding or increased risk of bleeding, or receiving palliative care and publications available only in abstract form or meeting reports. Studies with inadequate information about enteral feeding were also excluded. We contacted the authors if the data on predefined outcomes from their studies were required.

\section{Data extraction and quality assessment}

Two reviewers ( $\mathrm{H}-\mathrm{BH}$ and $\mathrm{W} \mathrm{J})$ independently extracted data from included studies, such as the first author, year of publication, country, sample size, study design, setting, treatment protocol for SUP and comparator, severity of illness, and all predefined outcomes. Quality of included studies was evaluated using the risk of bias tool recommended by the Cochrane Collaboration [25]. We assigned a value of high, unclear, or low to the following items: sequence generation; allocation concealment; blinding; incomplete outcome data; selective outcome reporting; and other sources of bias. Discrepancies were identified and resolved through discussion.

\section{Outcomes and statistical analysis}

The primary outcome was bleeding rate, which was defined as overt GI bleeding (if reported in the enrolled studies) or clinically important GI bleeding (if overt GI bleeding was not reported in the enrolled studies). Secondary outcomes included incidence of HAP, overall mortality, C. difficile infection, length of ICU stay, and duration of mechanical ventilation. When the outcome of HAP was unavailable, the rate of VAP was used. The results from all relevant studies were merged to estimate the pooled risk ratio (RR) and associated 95\% confidence intervals (CIs) for dichotomous outcomes. As to the continuous outcomes, mean difference (MD) and 95\% CI was estimated as the effect result. Some studies reported the median as the measure of treatment effect, with accompanying interquartile range (IQR). Before data analysis, we estimated the mean from the median and standard deviation (SD) from the IQR using methods described in previous studies [26].

Heterogeneity was tested with $I^{2}$ statistics. $I^{2}<50 \%$ was considered to indicate insignificant heterogeneity and a fixed-effect model was used, whereas a random- 
effect model was used in cases of significant heterogeneity $\left(I^{2}>50 \%\right)$. To explore the robustness and the potential influence of factors of our primary outcome, we performed subgroup analyses including type of SUP drugs (sucralfate, PPIs or $\mathrm{H}_{2} \mathrm{RAs}$ ), route of administration (enteral or intravenous), study design (blinded or unblinded), sample size $(<100$ or $>100)$, published year (before year 2000 or after year 2000), and clinical setting (medical, surgery, or mixed ICU). We also conducted sensitivity analyses on GI bleeding by pooling studies only focusing on: (a) overt GI bleeding; (b) clinically important GI bleeding; (c) a randomized-effects model; and (d) early EN (initiated within 48 hours of ICU admission). Publication bias was deemed to be evaluated by visually inspecting funnel plots when at least 10 studies were included in this meta-analysis. A $p$ value $<0.05$ was considered statistically significant. All statistical analyses were performed using Review Manager, Version 5.3.

\section{Result}

\section{Study selection}

A flowchart of the search strategy and the reasons for exclusion are shown in Fig. 1. The initial search identified a total of 533 citations: 155 studies were excluded because of duplicate studies, and 362 studies were excluded based on reviews of the title and abstract. Thus, 16 studies were full-text read for further evaluation. Of these 16 studies, 9 were excluded because they did not provide sufficient information on EN (Additional file 1: S2). Finally, the remaining seven RCTs, which

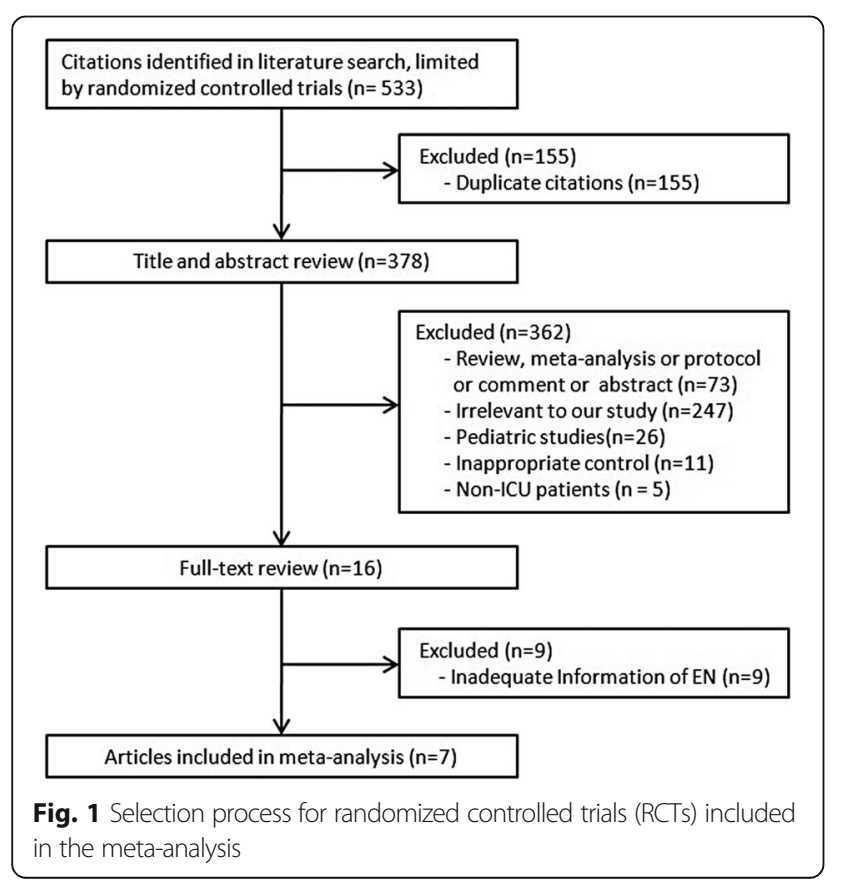

enrolled 889 patients, were included in our final analysis $[18,21-23,27-29]$.

\section{Study characteristics and quality}

The main characteristics and predefined outcome data of the included RCTs are described in Tables 1 and 2 . The variable definitions of GI bleeding and HAP are summarized in Additional file 1: file S3. These studies were published between 1985 and 2017, with sample sizes ranging from 28 to 300 patients. Four out of the seven RCTs used placebo as the comparator [18, 23, 27, $29]$, while the other three used no prophylaxis [21, 22, 28]. As for the type of prophylaxis drugs used, $\mathrm{H}_{2} \mathrm{RAs}$ and PPI were used in four [18, 27-29] and three studies [21-23], respectively, whereas $\mathrm{H}_{2} \mathrm{RAs}$ and sucralfate were used in one study [22]. During the study period, all patients received adequate EN (61-100\%). Overt GI bleeding was reported in six RCTs [18, 21, 23, 27, 29], while three studies reported clinically important bleeding $[18,22,28]$. The Cochrane risk of bias score for each citation varied across the studies (Additional file 1: file S4). We did not assess the publication bias because of the limited number $(<10)$ of studies included in each analysis.

\section{Primary outcome}

GI bleeding was reported in all seven RCTs. The pooled analysis showed that, in enterally fed patients, SUP did not reduce the risk of GI bleeding (7 studies; $\mathrm{n}=889$, RR 0.80 ; $95 \% \mathrm{CI}, 0.49$ to $1.31 ; I^{2}=8 \% ; p=0.96$ ) (Fig. 2). Although there was no significant heterogeneity, we proceeded to perform stratified analyses across predefined key study characteristics and clinical factors. In general, all the subgroup analyses confirmed similar rates of GI bleeding among groups. Sensitivity analyses were subsequently conducted, and suggested that when only clinically important GI bleeding or overt GI bleeding or randomized-effects models or early EN were considered, there was no difference between groups. Details of the results of subgroup analyses and sensitivity analyses are shown in Table 3.

\section{Secondary outcomes}

There was no statistically significant difference between the SUP and the no SUP groups in overall mortality (6 studies, $\mathrm{n}=861 ; \mathrm{RR} 1.21 ; 95 \%$ CI, 0.94 to $1.56 ; I^{2}=0 \% ; p=0.14$ ) [18, 21, 22, 27-29] (Fig. 3a) or C. difficile infection (3 studies, $\mathrm{n}=407$; RR 0.89 ; $95 \%$ CI, 0.29 to $3.19 ; I^{2}=0 \% ; p=0.86$ ) $[18,27,29]$ (Fig. 3b). The length of stay in the ICU (4 studies, $\mathrm{n}=707, \mathrm{MD} 0.04$ days; $95 \% \mathrm{CI},-0.79$ to $0.87, I^{2}=48 \%$; $p=0.92$ ) [18, 22, 27, 29] (Fig. 3c) and duration of mechanical ventilation ( 4 studies, $\mathrm{n}=707, \mathrm{MD}-0.38$ days; $95 \% \mathrm{CI}$, -1.48 to $\left.0.72, I^{2}=17 \% ; p=0.50\right)[18,22,27,29]$ (Fig. 3d) were also similar. The incidence of HAP was higher in SUP group (5 studies, $\mathrm{n}=407$; RR 1.53; 95\% CI, 1.04 to $2.27 ; I^{2}$ 
Table 1 Characteristics of the included studies

\begin{tabular}{|c|c|c|c|c|c|c|c|c|c|}
\hline \multirow[t]{2}{*}{ Study/year } & \multirow{2}{*}{$\begin{array}{l}\text { Sample size } \\
(\mathrm{I} / \mathrm{C})\end{array}$} & \multirow[t]{2}{*}{ Setting } & \multirow[t]{2}{*}{ Prophylaxis drugs } & \multirow[t]{2}{*}{ Comparator } & \multicolumn{5}{|c|}{ Patient characteristics (I/C) } \\
\hline & & & & & $\begin{array}{l}\text { Age, mean, } \\
\text { (years) }\end{array}$ & $\begin{array}{l}\text { Disease severity, median (IQR) or } \\
\text { mean (SD) }\end{array}$ & $\begin{array}{l}\text { Patient receiving } \\
\mathrm{EN}, \mathrm{n} / \mathrm{N}(\%)\end{array}$ & $\begin{array}{l}\mathrm{MV} \\
(\%)\end{array}$ & $\begin{array}{l}\text { Follow up } \\
\text { (months) }\end{array}$ \\
\hline $\begin{array}{l}\text { Alhazzani et al. } 2017 \\
{[18]}\end{array}$ & $49 / 42$ & Mixed & $\begin{array}{l}\text { Pantoprazole } 40 \mathrm{mg} \\
\text { once daily IV }\end{array}$ & Placebo & $62 / 55$ & $\begin{array}{l}\text { APACHE II score } \\
21(17-26) / 22(14-27)\end{array}$ & $81 / 91(89)$ & $\begin{array}{l}100 / \\
100\end{array}$ & Unknown \\
\hline $\begin{array}{l}\text { El-Kersh et al. } \\
2017 \text { [29] }\end{array}$ & $55 / 47$ & MICU & $\begin{array}{l}\text { Pantoprazole } 40 \mathrm{mg} \\
\text { once daily IV }\end{array}$ & Placebo & $62 / 58$ & $\begin{array}{l}\text { SAPS II score } \\
41(34.5-53) / 44(34-54)\end{array}$ & 102/102 (100) & $\begin{array}{l}100 / \\
100\end{array}$ & Unknown \\
\hline $\begin{array}{l}\text { Selvanderan } \\
\text { et al. } 2016 \text { [27] }\end{array}$ & $106 / 108$ & Mixed & $\begin{array}{l}\text { Pantoprazole } 40 \mathrm{mg} \\
\text { once daily IV }\end{array}$ & Placebo & $52 / 52$ & $\begin{array}{l}\text { APACHE III score } \\
66(26) / 66(28)\end{array}$ & 214/214 (100) & $\begin{array}{l}100 / \\
100\end{array}$ & 12 \\
\hline Lin et al. 2016 [28] & $60 / 60$ & Mixed & $\begin{array}{l}\text { Lansoprazole OD } \\
30 \text { mg once daily }\end{array}$ & $\begin{array}{l}\text { No } \\
\text { prophylaxis }\end{array}$ & $67 / 65$ & $\begin{array}{l}\text { APACHE II score } \\
21.3(6.7) / 19.9(6.9)\end{array}$ & 120/120 (100) & $\begin{array}{l}100 / \\
100\end{array}$ & 1 \\
\hline $\begin{array}{l}\text { Ben-menachem } \\
\text { et al. } 1994 \text { [22] }\end{array}$ & 200/100 & MICU & $\begin{array}{l}\text { Cimetidine } 900 \text { mg } \\
\text { Infusion } \\
\text { Sucralfate OD } 1 \mathrm{~g} \\
\text { every } 6 \mathrm{~h}\end{array}$ & $\begin{array}{l}\text { No } \\
\text { prophylaxis }\end{array}$ & $60 / 60$ & $\begin{array}{l}\text { APACHE II score } \\
17.4(7.3) / 16.5(6.9)\end{array}$ & 198/300 (67) & $74 / 65$ & 10 \\
\hline $\begin{array}{l}\text { Apte et al. } 1992 \\
\text { [21] }\end{array}$ & $16 / 18$ & MICU & $\begin{array}{l}\text { Ranitidine } 50 \mathrm{mg} \text { /every } \\
6 \mathrm{~h} \mathrm{IV}\end{array}$ & $\begin{array}{l}\text { No } \\
\text { prophylaxis }\end{array}$ & $27 / 26$ & $\begin{array}{l}\text { MTS score } \\
11(4-16) / 10(6-16)\end{array}$ & $34 / 34(100)$ & $31 / 22$ & Unknown \\
\hline $\begin{array}{l}\text { Van den Berg } \\
\text { et al. } 1985[23]\end{array}$ & $14 / 14$ & Mixed & $\begin{array}{l}\text { Cimetidine } 20 \text { mg/kg/ } \\
\text { every } 24 \text { h IV }\end{array}$ & Placebo & $44 / 48$ & - & $17 / 28(61)$ & $\begin{array}{l}100 / \\
100\end{array}$ & Unknown \\
\hline
\end{tabular}

APACHE II acute physiology and chronic health evaluation II, EN enteral nutrition, IQR interquartile range, I/C intervention/control, $I V$ intravenous, MTS maximum tetanus severity score, MICU medical intensive care unit, Mixed medical-surgical intensive care unit, MV mechanical ventilation, OD once daily, SAPS // simplified acute physiologic score II, SD standard deviation

$=0 \% ; p=0.03)[18,21,22,27,28]$ (Fig. 3e), while the incidence of VAP was comparable between groups ( 3 studies, $\mathrm{n}$ $=425 ; \mathrm{RR} 1.24 ; 95 \% \mathrm{CI}, 0.72$ to $\left.2.15 ; I^{2}=0 \% ; p=0.44\right)$ (Fig. 3f) $[18,27,28]$.

\section{Discussion}

Our meta-analysis showed that, among ICU patients receiving enteral feeding, pharmacologic SUP exerted no impact on the risk of GI bleeding, overall mortality, $C$. difficile infection, duration of MV and length of ICU stay, but led to an increased risk of HAP.

In this updated meta-analysis, we found that there was no added benefit with concomitant pharmacologic SUP in GI bleeding once patients were receiving enteral feeding. This finding expanded on the earlier metaanalyses to provide better evidence for pharmacologic SUP in enterally fed patients in the ICU [4]. First, our meta-analysis had a larger sample size than the previous meta-analyses as it included four RCTs published between 2016 and 2017, with more power to assess this effect. Second, the subgroup and sensitivity analyses based on various clinical characteristics did not significantly alter our main findings. Finally, we further evaluated other related important outcomes (e.g., duration of mechanical ventilation, overall mortality, and length of stay in the ICU) and found no difference between groups, thus providing evidence of the robustness of our results.

Apart from calorie delivery, EN had also been found to protect against stress-related GI bleeding [4, 14-16]. EN might mitigate macroscopic ulceration by optimizing mucosal energy, intramucosal $\mathrm{pH}[17,30]$ and regional distribution of gastrointestinal blood flow [31, 32]. In addition, EN was able to reduce GI inflammation secondary to reperfusion injury. To date, there had been no RCTs comparing GI bleeding rates in critically ill patients receiving EN versus no EN. Several case series

Table 2 Predefined outcome of included studies

\begin{tabular}{|c|c|c|c|c|c|c|c|c|c|c|c|c|c|c|}
\hline \multirow[t]{2}{*}{ Study/year } & \multicolumn{2}{|c|}{ Gl bleeding } & \multicolumn{2}{|c|}{ Mortality } & \multicolumn{2}{|c|}{ Pneumonia } & \multicolumn{2}{|l|}{ CDI } & \multicolumn{2}{|l|}{ VAP } & \multicolumn{2}{|l|}{ Duration of MV } & \multicolumn{2}{|c|}{ Length of ICU stay } \\
\hline & SUP & Control & SUP & Control & SUP & Control & SUP & Control & SUP & Control & SUP & Control & SUP & Control \\
\hline Alhazzani 2017 [18] & $4 / 49$ & $3 / 42$ & $17 / 49$ & $13 / 42$ & $10 / 49$ & $6 / 42$ & $2 / 49$ & $1 / 42$ & $10 / 49$ & $6 / 42$ & $9(5-17)$ & $\begin{array}{l}6.5 \\
(4-14)\end{array}$ & $12(8-23)$ & $8.5(6-18)$ \\
\hline El-Kersh 2017 [29] & $1 / 55$ & $1 / 47$ & $7 / 55$ & $8 / 47$ & - & - & $1 / 55$ & $3 / 47$ & & & $4(2.2-7)$ & $5(3-8)$ & $6(4-6.9)$ & $7(3.5-11.5)$ \\
\hline $\begin{array}{l}\text { Selvanderan } 2016 \\
\text { [27] }\end{array}$ & $3 / 106$ & $6 / 108$ & $30 / 106$ & $25 / 108$ & $12 / 106$ & $8 / 108$ & $1 / 106$ & $0 / 108$ & $12 / 106$ & $8 / 108$ & $21(0-25)$ & $\begin{array}{l}21 \\
(4-25)\end{array}$ & $6(3-11)$ & $7(4-14)$ \\
\hline Lin 2016 [28] & $0 / 60$ & $6 / 60$ & $2 / 60$ & $0 / 60$ & $4 / 60$ & $6 / 60$ & - & - & $4 / 60$ & $6 / 60$ & - & - & - & - \\
\hline $\begin{array}{l}\text { Ben-menachem } 1994 \\
\text { [22] }\end{array}$ & $\begin{array}{l}10 / \\
200\end{array}$ & $6 / 200$ & $\begin{array}{l}45 / \\
200\end{array}$ & $19 / 100$ & $\begin{array}{l}25 / \\
200\end{array}$ & $6 / 100$ & - & - & & & $7.3(8.9) / 8.1(1.1)$ & $7.9(9.6)$ & $\begin{array}{l}3(2-8.5) / 4 \\
(2-9)\end{array}$ & $3(2-8)$ \\
\hline Apte 1992 [21] & $5 / 16$ & $6 / 18$ & $11 / 16$ & $7 / 18$ & $11 / 16$ & $7 / 18$ & - & - & & & - & - & - & - \\
\hline Van den Berg 1985 [23] & $5 / 14$ & $1 / 14$ & - & - & - & - & - & - & & & - & - & - & - \\
\hline
\end{tabular}

$C D I$ Clostridium difficile infection, GI gastrointestinal, $M V$ mechanical ventilation, SUP stress ulcer prophylaxis, VAP ventilator associated pneumonia Continuous data are given as median (25th-75th percentile), mean (standard deviation, SD) 


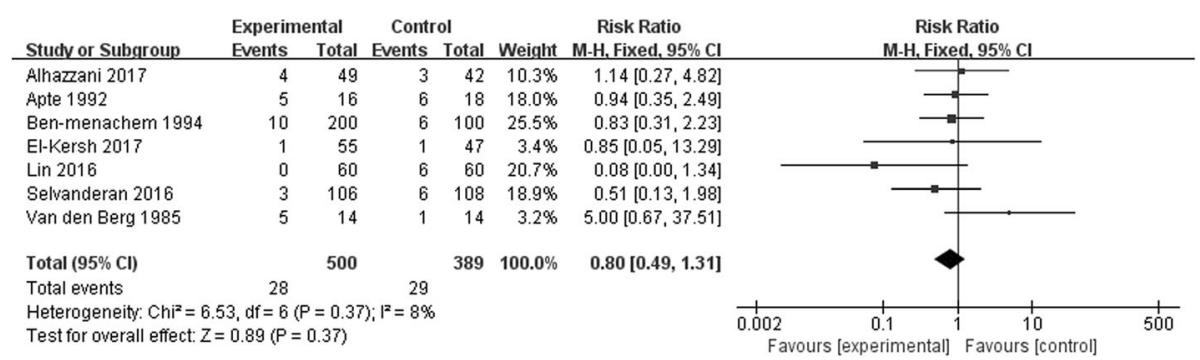

Fig. 2 Forest plot showing the effect of stress ulcer prophylaxis for gastrointestinal bleeding. M-H Mantel-Haenszel

involving a total of 749 patients reported that enterally fed critically ill patients in the absence of pharmacologic SUP was associated with bleeding rates of $8.4-8.8 \%$ [3, 33]. In our study, we also found a similar bleeding rate (7.5\%) in patients receiving EN alone. In comparison, Marik et al. reported a GI bleeding rate of $15.8 \%$ in the subgroup of patients without EN or any pharmacologic SUP [4]. A similar incidence (17.5\%) was also identified in a recent meta-analysis in unfed patients [19]. These data suggest a potential role of EN against stress-related GI bleeding, therefore questioning any added benefits of pharmacologic SUP in patients already receiving EN.

Our results indicated that pharmacologic SUP in enterally fed patients is associated with higher incidence of HAP, which is consistent with the previous metaanalysis [4]. The reason might be that concomitant EN and pharmacologic SUP would result in a significantly higher $\mathrm{pH}$ than either intervention alone [17]. However, we should interpret this finding cautiously. First, the definitions of HAP varied across included studies, with the incidence ranging from 8.4 to $52.9 \%[18,21-23,27-$ 29]. Second, the included studies had spanned a period of more than three decades, when co-interventions had been developed and quality improvement approaches such as guidelines for HAP/VAP prevention had been introduced and updated [34]. This, to some extent, might affect the accurate evaluation of the effects of SUP. In fact, the significant increase in pneumonia was

Table 3 Further subgroup analysis and sensitivity analyses on primary outcome of gastrointestinal bleeding rate

\begin{tabular}{|c|c|c|c|c|c|c|c|c|}
\hline & & Studies, number & $\begin{array}{l}\text { Patients, } \\
\text { number }\end{array}$ & $\begin{array}{l}\text { Event in SUP } \\
\text { group }\end{array}$ & Event in control group & Risk ratio $(95 \% \mathrm{Cl})$ & $P^{2}$ & $p$ \\
\hline \multicolumn{9}{|l|}{ Subgroup analyses } \\
\hline \multirow[t]{3}{*}{ Type of SUP } & PPI & 4 & 527 & 8 of 270 & 16 of 257 & $0.49(0.21,1.10)$ & $4 \%$ & 0.08 \\
\hline & $\mathrm{H}_{2} \mathrm{RA}$ & 3 & 262 & 20 of 130 & 13 of 132 & $1.60(0.86,3.05)$ & $16 \%$ & 0.15 \\
\hline & Sucralfate & 1 & 200 & 5 of 100 & 6 of 100 & $0.83(0.26,2.64)$ & - & 0.76 \\
\hline \multirow[t]{2}{*}{ Published year } & After 2000 & 4 & 527 & 8 of 270 & 16 of 257 & $0.49(0.21,1.10)$ & $4 \%$ & 0.08 \\
\hline & Before 2000 & 3 & 362 & 20 of 230 & 13 of 132 & $0.75(0.30,1.86)$ & $0 \%$ & 0.53 \\
\hline \multirow[t]{2}{*}{ Sample size } & $<100$ & 3 & 153 & 14 of 79 & 10 of 74 & $1.42(0.68,2.94)$ & $12 \%$ & 0.35 \\
\hline & $>100$ & 4 & 736 & 14 of 421 & 19 of 315 & $0.52(0.26,1.04)$ & $0 \%$ & 0.07 \\
\hline \multirow[t]{2}{*}{ Study designed } & Blinded & 4 & 435 & 13 of 224 & 11 of 211 & $1.12(0.52,2.44)$ & $0 \%$ & 0.77 \\
\hline & Unblinded & 3 & 454 & 15 of 276 & 18 of 178 & $0.62(0.32,1.19)$ & $35 \%$ & 0.15 \\
\hline \multirow[t]{2}{*}{ Setting } & $\mathrm{MICU}$ & 3 & 436 & 16 of 271 & 13 of 165 & $0.87(0.44,1.73)$ & $0 \%$ & 0.70 \\
\hline & Mixed ICU & 4 & 453 & 12 of 229 & 16 of 224 & $0.73(0.36,1.50)$ & $0 \%$ & 0.73 \\
\hline \multirow{2}{*}{$\begin{array}{l}\text { Administration } \\
\text { route }\end{array}$} & Oral & 2 & 669 & 23 of 340 & 23 of 329 & $1.0(0.58,1.72)$ & $0 \%$ & 1.00 \\
\hline & Intravenous & 6 & 320 & 5 of 160 & 12 of 160 & $0.35(0.03,3.84)$ & $62 \%$ & 0.39 \\
\hline \multicolumn{9}{|l|}{ Sensitivity analyses } \\
\hline \multirow[t]{4}{*}{ Gl bleeding } & Overt GI bleeding & 6 & 589 & 18 of 300 & 23 of 289 & $0.79(0.44,1.39)$ & $24 \%$ & 0.41 \\
\hline & Clinical important Gl bleeding & 4 & 725 & 13 of 415 & 13 of 310 & $0.63(0.29,1.37)$ & $25 \%$ & 0.25 \\
\hline & Randomized-effects models & 7 & 889 & 28 of 500 & 29 of 389 & $0.87(0.50,1.53)$ & $8 \%$ & 0.63 \\
\hline & Early enteral nutrition & 6 & 798 & 24 of 451 & 26 of 347 & $0.76(0.49,1.29)$ & $22 \%$ & 0.31 \\
\hline
\end{tabular}




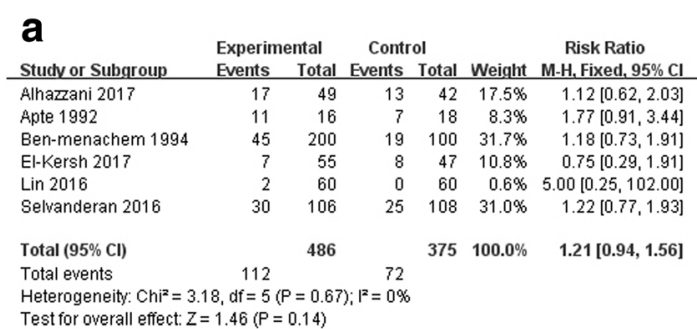

Test for overall effect $Z=1.46(P=0.14)$
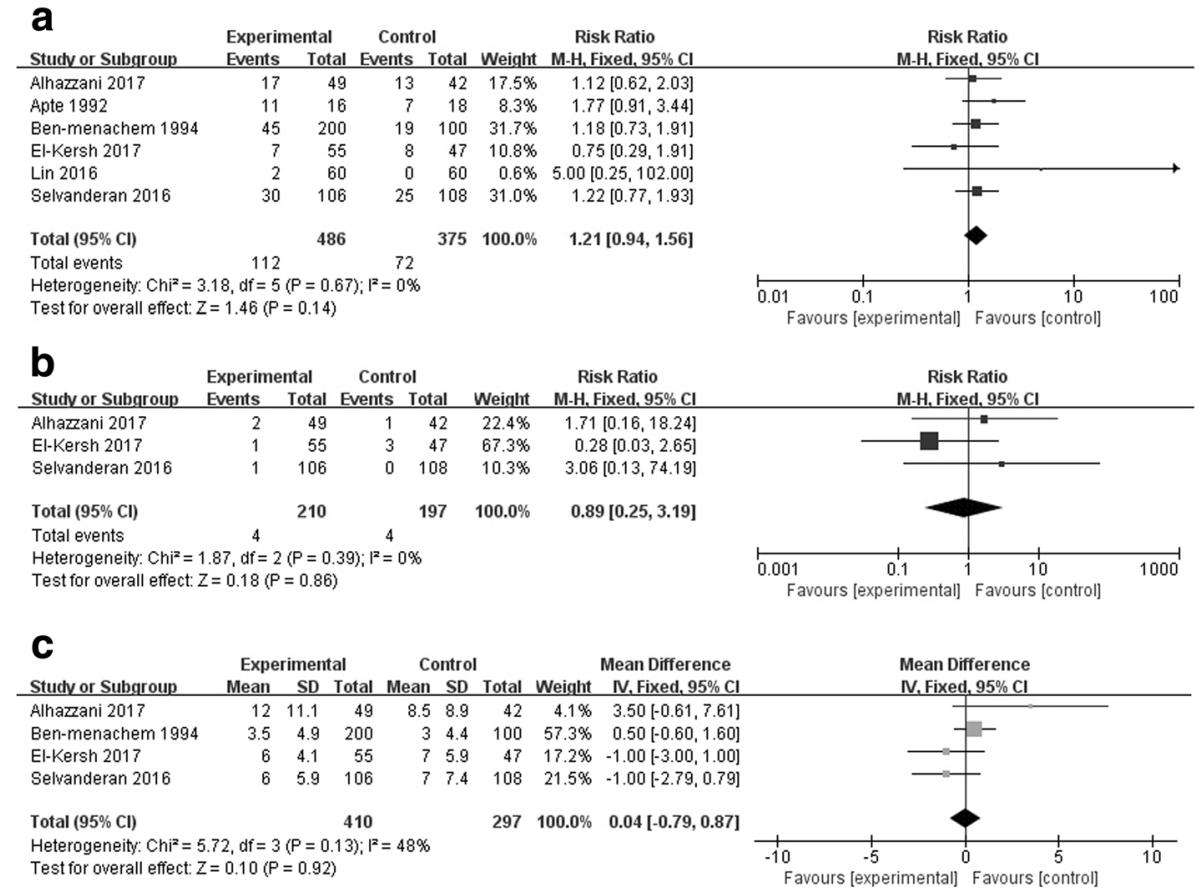

d
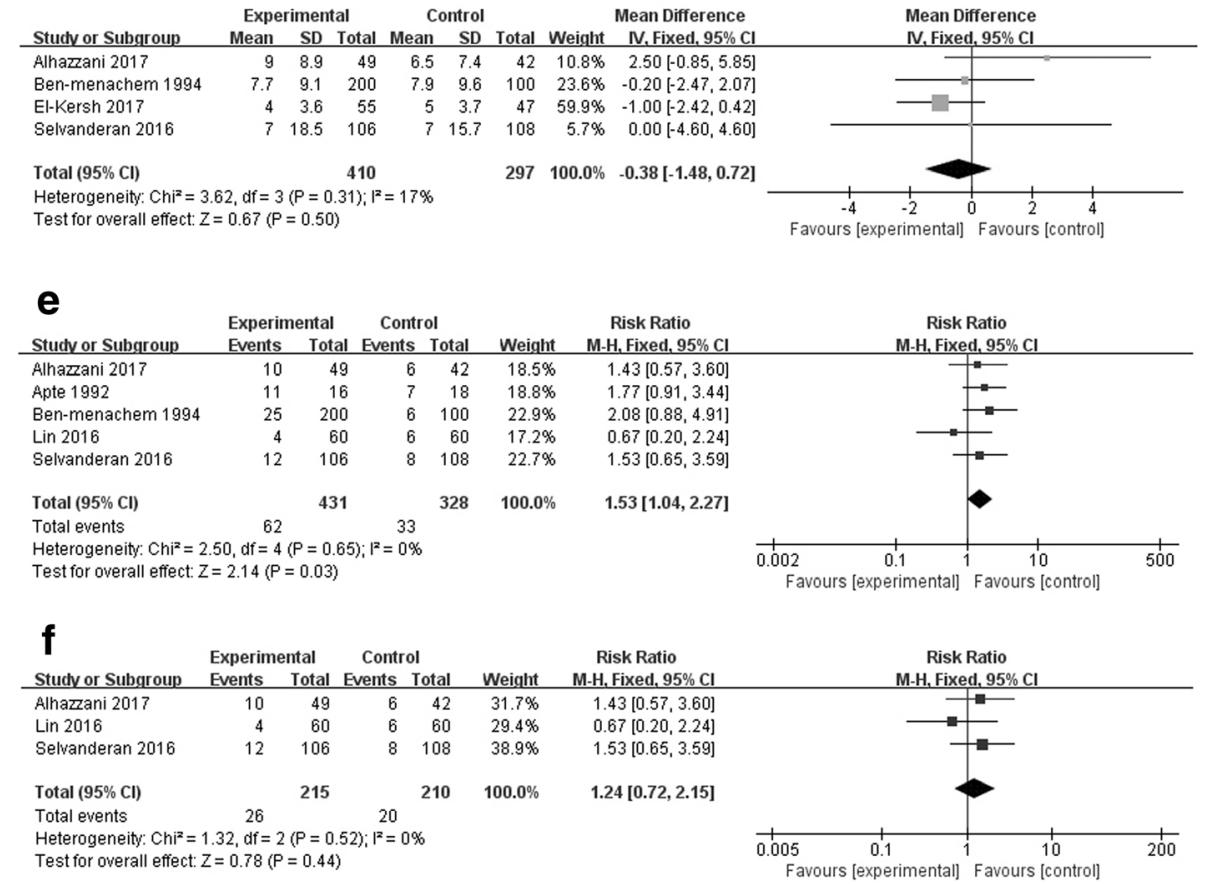

Fig. 3 Forest plot showing the effect of stress ulcer prophylaxis on overall mortality (a), Clostridium difficile infection (b), length of intensive care unit stay (c), duration of mechanical ventilation (d), hospital-acquired pneumonia (e) and ventilator-associated pneumonia (f) M-H Mantel-Haenszel

mainly caused by the two earlier trials [21, 22], but not the newly published RCTs $[18,27,28]$. When only the three RCTs that focused on VAP were considered, no differences were found between groups [18, 27, 28]. Finally, we did not find significant differences in terms of other secondary outcomes (e.g., mortality, duration of mechanical ventilation, or length of stay in the ICU). Recently, more and more attention had been paid to the possible association between the SUP strategy and enteric infections, particularly $C$. difficile [13]. Several epidemiological investigations and meta-analyses had demonstrated an increased risk of $C$. difficile infection in 
patients under a SUP strategy. In addition, studies suggested that PPIs were more strongly associated with this enteric infection than $\mathrm{H}_{2}$ RAs $[12,13]$. However, these results could not place sufficient weight on RCT evidence. It was noteworthy that no study had investigated the effect of $\mathrm{EN}$ on $C$. difficile infection. Our results suggested that in enterally fed patients the rate of C. difficile infection was similar in the SUP and nonSUP groups (1.9\% vs. $2.0 \%)$. The relatively small number of events may account for these negative results. Therefore, further well-designed, large RCTs are warranted to focus on this topic, as the detrimental outcomes of these serious infections may outweigh the benefit of SUP.

Recently, there has been growing interest in PPIs as a means of SUP. For example, all four additional RCTs included in our meta-analysis compared the effect of PPIs with placebo. Moreover, PPIs were also increasingly prescribed as the primary SUP agent, ranging from 39.6 to $70 \%$ in critically ill patients $[8,35]$. In a recent international survey, PPIs were the most comment agent (66\%) used for SUP [1]. This might be due to the superiority of PPIs in reducing GI bleeding, as suggested by several meta-analyses [20,36], and the recommendations of the Surviving Sepsis Campaign [37]. Despite the widespread use of PPIs, the effect of concomitant EN in this SUP procedure is rarely evaluated. In our study, only four included RCTs focused on this topic, and pooled results suggested no benefit or harm associated with PPIs. Though limited by the small sample, our data may, at the very least, encourage clinicians to reevaluate their practice in prescribing prophylactic PPIs in critically ill patients. As a matter of fact, several ongoing RCTs comparing PPIs with placebo in ICU patients with high risk of GI bleeding may provide more convincing evidence in the future [38-40].

Our study has some limitations. First, only seven studies were included in our analysis, and most of them had a sample size of less than 200 [18, 21, 23, 28, 29], which would more likely result in overestimation of effect size. Thus, further studies in large cohorts are needed to validate our findings. Second, there were differences among included trials with regards to the adopted definition of GI bleeding, timing and duration of EN, and patient intolerance of $\mathrm{EN}$, which might lead to the observed heterogeneity, and therefore compromise the robustness of our findings. Third, the uneven distribution of different underlying diseases among included studies might also exert a prognostic value. We planned to perform subgroup analyses to explore studies based on such diversities, which was hampered by nsufficient data. Fourth, although predefined subgroup analyses had been performed, some results of subgroups should be interpreted with caution due to small number of patients. Finally, we had not pre-published this updated metaanalysis protocol in a registry.

\section{Conclusion}

In summary, based on available data, our results demonstrate that in ICU patients receiving EN, pharmacologic SUP offered no beneficial effect on the incidence of GI bleeding and other clinically important outcomes. Large-scale, well-designed RCTs will be needed to confirm our findings.

\section{Key messages}

- In patients receiving EN in the ICU, pharmacologic SUP showed no beneficial effect on GI bleeding, overall mortality, Clostridium difficile infection, length of stay in the ICU or duration of mechanical ventilation, but was associated with an increased incidence of HAP.

- Further larger adequately powered RCTs with rigorous definitions and designs are warranted to confirm our results.

\section{Additional file}

Additional file 1: S1. PICO question. S2. Excluded RCTs that did not provide sufficient information on EN. S3. Definitions of Gl bleeding and nosocomial pneumonia in the included RCTs. S4. Risk of bias graph and summary of the included RCTs. (DOCX $39 \mathrm{~kb}$ )

\begin{abstract}
Abbreviations
Cls: Confidence intervals; EN: Enteral nutrition; Gl: Gastrointestinal:

$\mathrm{H}_{2}$ RAs: Histamine 2 receptor antagonists; HAP: Hospital-acquired pneumonia; ICU: Intensive care unit; IQR: Interquartile range; MD: Mean difference; PPIs: Proton pump inhibitors; RCTs: Randomized controlled trials; RR: risk ratio; SD: Standard deviation; SUP: Stress ulcer prophylaxis; VAP: Ventilatorassociated pneumonia
\end{abstract}

Acknowledgements

Not applicable.

Funding

No external funding was required for this research.

Availability of data and materials

All data generated or analysed during this study are included in this published article.

\section{Authors' contributions}

$\mathrm{H}-\mathrm{BH}$ searched the scientific literature and drafted the manuscript. WJ and $\mathrm{H}-\mathrm{YQ}$ contributed to conception, design and data interpretation. H-YQ and C-Y W helped to collect the data and performed statistical analyses. BD contributed to conception, design, data interpretation, manuscript revision for critical intellectual content and supervision of the study. All authors read and approved the manuscript.

Ethics approval and consent to participate Not applicable.

Consent for publication

Not applicable.

Competing interests

The authors declare that they have no competing interests. 


\section{Publisher's Note}

Springer Nature remains neutral with regard to jurisdictional claims in published maps and institutional affiliations.

\section{Author details}

'Medical ICU, Peking Union Medical College Hospital, Peking Union Medical College and Chinese Academy of Medical Sciences, 1 Shuai Fu Yuan, Beijing 100730, People's Republic of China. ${ }^{2}$ Department of Critical Care Medicine, the First Affiliated Hospital of Fujian Medical University, 20 Chazhong Road, Fuzhou 350000, People's Republic of China.

\section{Received: 5 November 2017 Accepted: 27 December 2017} Published online: 28 January 2018

\section{References}

1. Krag M, Perner A, Wetterslev J, Wise MP, Borthwick M, Bendel S, McArthur C, Cook D, Nielsen N, Pelosi $P$, et al. Stress ulcer prophylaxis in the intensive care unit: an international survey of 97 units in 11 countries. Acta Anaesthesiol Scand. 2015;59(5):576-85.

2. Faisy $C$, Guerot $E$, Diehl JL, Iftimovici E, Fagon JY. Clinically significant gastrointestinal bleeding in critically ill patients with and without stressulcer prophylaxis. Intensive Care Med. 2003;29(8):1306-13.

3. Zandstra DF, Stoutenbeek CP. The virtual absence of stress-ulceration related bleeding in ICU patients receiving prolonged mechanical ventilation without any prophylaxis. A prospective cohort study. Intensive Care Med. 1994;20(5):335-40.

4. Marik PE, Vasu T, Hirani A, Pachinburavan M. Stress ulcer prophylaxis in the new millennium: a systematic review and meta-analysis. Crit Care Med. 2010:38(11):2222-28.

5. Guillamondegui OD, Gunter OL Jr, Bonadies JA, Coates JE, Kurek SJ, De Moya MA, Sing RF, Sori AJ. Practice management guidelines for stress ulcer prophylaxis. Chicago: Eastern Association for the Surgery of Trauma. 2008:124

6. Tryba M, Cook D. Current guidelines on stress ulcer prophylaxis. Drugs. 1997:54(4):581-96.

7. Daley RJ, Rebuck JA, Welage LS, Rogers FB. Prevention of stress ulceration: current trends in critical care. Crit Care Med. 2004;32(10):2008.

8. Eastwood GM, Litton E, Bellomo R, Bailey MJ, Festa M, Beasley RW Young PJ. Opinions and practice of stress ulcer prophylaxis in Australian and New Zealand intensive care units. Crit Care Resusc. 2014;16(3):170-74.

9. Shears M, Alhazzani W, Marshall JC, Muscedere J, Hall R, English SW, Dodek PM, Lauzier F, Kanji S, Duffett M, et al. Stress ulcer prophylaxis in critical illness: a Canadian survey. Can J Anaesth. 2016;63(6):718-24.

10. Farley KJ, Barned KL, Crozier TM. Inappropriate continuation of stress ulcer prophylaxis beyond the intensive care setting. Crit Care Resusc 2013;15(2):147-51

11. Miano TA, Reichert MG, Houle $\Pi$, Macgregor DA, Kincaid EH, Bowton DL. Nosocomial pneumonia risk and stress ulcer prophylaxis: a comparison of pantoprazole vs ranitidine in cardiothoracic surgery patients. Chest. 2009;136(2):440.

12. Azab M, Doo L, Doo DH, Elmofti Y, Ahmed M, Cadavona JJ, Liu XB, Shafi A, Joo MK, Yoo JW. Comparison of the hospital-acquired clostridium difficile infection risk of using proton pump inhibitors versus histamine-2 receptor antagonists for prophylaxis and treatment of stress ulcers: a systematic review and meta-analysis. Gut Liver. 2017;11(6):781-8.

13. Leonard J, Marshall JK, Moayyedi P. Systematic review of the risk of enteric infection in patients taking acid suppression. Am J Gastroenterol. 2007; 102(9):2047-56. quiz 2057.

14. Pingleton SK, Hadzima SK. Enteral alimentation and gastrointestinal bleeding in mechanically ventilated patients. Crit Care Med. 1983;11(1):13.

15. Ephgrave KS, Kleimanwexler RL, Adair CG. Enteral nutrients prevent stress ulceration and increase intragastric volume. Crit Care Med. 1990;18(6):621.

16. Inoue S, Lukes S, Alexander JW, Trocki O, Silberstein EB. Increased gut blood flow with early enteral feeding in burned guinea pigs. J Burn Care Rehabil. 1989;10(4):300.

17. Bonten MJ, Gaillard CA, van Tiel FH, van der Geest S, Stobberingh EE. Continuous enteral feeding counteracts preventive measures for gastric colonization in intensive care unit patients. Crit Care Med. 1994;22(6):939-44.
18. Alhazzani W, Guyatt G, Alshahrani M, Deane AM, Marshall JC, Hall R, Muscedere $J$, English SW, Lauzier $F$, Thabane L, et al. Withholding pantoprazole for stress ulcer prophylaxis in critically ill patients: a pilot randomized clinical trial and meta-analysis. Crit Care Med. 2017:45(7):1121-29.

19. Krag M, Perner A, Wetterslev J, Wise MP, Hylander MM. Stress ulcer prophylaxis versus placebo or no prophylaxis in critically ill patients. A systematic review of randomised clinical trials with meta-analysis and trial sequential analysis. Intensive Care Med. 2014;40(1):11-22.

20. Alhazzani W, Alenezi F, Jaeschke RZ, Moayyedi P, Cook DJ. Proton pump inhibitors versus histamine 2 receptor antagonists for stress ulcer prophylaxis in critically ill patients: a systematic review and meta-analysis. Crit Care Med. 2013;41(3):693-705.

21. Apte NM, Karnad DR, Medhekar TP, Tilve GH, Morye S, Bhave GG. Gastric colonization and pneumonia in intubated critically ill patients receiving stress ulcer prophylaxis: a randomized, controlled trial. Crit Care Med. 1992;20(5):590-93.

22. Benmenachem T, Fogel R, Patel RV, Touchette M, Zarowitz BJ, Hadzijahic N, Divine G, Verter J, Bresalier RS. Prophylaxis for stress-related gastric hemorrhage in the medical intensive care unit. A randomized, controlled, single-blind study. Ann Intern Med. 1994;121(8):568-75.

23. Berg BVD, Blankenstein MV. Prevention of stress-induced upper gastrointestinal bleeding by cimetidine in patients on assisted ventilation. Digestion. 1985;31(1):1

24. Moher D, Liberati A, Tetzlaff J, Altman DG, Group P. Preferred reporting items for systematic reviews and meta-analyses: the PRISMA statement. Int J Surg. 2010;8(5):336-41.

25. Higgins JPT, Altman DG, Gøtzsche PC, Jüni P, Moher D, Oxman AD, Savović I. Schulz KF, Weeks L, Sterne JAC. The Cochrane Collaboration's tool for assessing risk of bias in randomised trials. BMJ. 2011;343:d5928.

26. Wan X, Wang W, Liu J, Tong T. Estimating the sample mean and standard deviation from the sample size, median, range and/or interquartile range. BMC Med Res Methodol. 2014;14(1):135

27. Selvanderan SP, Summers MJ, Finnis ME, Plummer MP, Ali Abdelhamid Y, Anderson MB, Chapman MJ, Rayner CK, Deane AM. Pantoprazole or placebo for stress ulcer prophylaxis (POP-UP): randomized double-blind exploratory study. Crit Care Med. 2016:44(10):1842-50.

28. Lin CC, Hsu YL, Chung CS, Lee TH. Stress ulcer prophylaxis in patients being weaned from the ventilator in a respiratory care center: a randomized control trial. J Formos Med Assoc. 2016;115(1):19-24.

29. El-Kersh K, Jalil B, McClave SA, Cavallazzi R, Guardiola J, Guilkey K, Persaud AK, Furmanek SP, Guinn BE, Wiemken TL, et al. Enteral nutrition as stress ulcer prophylaxis in critically ill patients: a randomized controlled exploratory study. J Crit Care. 2017:43:108-13.

30. Fiddian-Green RG, Mcgough E, Pittenger G, Rothman E. Predictive value of intramural $\mathrm{pH}$ and other risk factors for massive bleeding from stress ulceration. Gastroenterology. 1983;85(3):613-20.

31. Kazamias $P$, Kotzampassi $K$, Koufogiannis D, Eleftheriadis E. Influence of enteral nutrition-induced splanchnic hyperemia on the septic origin of splanchnic ischemia. World J Surg. 1998:22(1):6-11.

32. Braga M, Gianotti L, Gentilini O, Parisi V, Salis C, Di CV. Early postoperative enteral nutrition improves gut oxygenation and reduces costs compared with total parenteral nutrition. Crit Care Med. 2001; 29(2):242

33. Watson LC, Abston S. Prevention of upper gastrointestinal hemorrhage in 582 burned children. Am J Surg. 1976:132(6):790-93.

34. File Jr TM. Recommendations for treatment of hospital-acquired and ventilator-associated pneumonia: review of recent international guidelines. Clin Infect Dis. 2010;51 Suppl 1:S42-7.

35. Barletta JF, Erstad BL, Fortune JB. Stress ulcer prophylaxis in trauma patients. Crit Care. 2002:6(6):1-5.

36. Barkun AN, Bardou M, Pham CQ, Martel M. Proton pump inhibitors vs. histamine 2 receptor antagonists for stress-related mucosal bleeding prophylaxis in critically ill patients: a meta-analysis. Am J Gastroenterol. 2012:107(4):507-20.

37. Rhodes A, Evans LE, Alhazzani W, Levy MM, Antonelli M, Ferrer R, Kumar A, Sevransky JE, Sprung CL, Nunnally ME, et al. Surviving sepsis campaign: international guidelines for management of sepsis and septic shock: 2016. Intensive Care Med. 2017:43(3):304-77.

38. Krag M, Perner A, Wetterslev J, Wise MP, Borthwick M, Bendel S, Pelosi $P$, Keus F, Guttormsen AB, Schefold JC, et al. Stress ulcer prophylaxis with a proton pump inhibitor versus placebo in critically ill patients 
(SUP-ICU trial): study protocol for a randomised controlled trial. Trials. 2016;17(1):205.

39. Krag M, Perner A, Wetterslev J, Lange T, Wise MP, Borthwick M, Bendel S, Pelosi P, Keus F, Guttormsen AB, et al. Stress ulcer prophylaxis in the intensive care unit trial: detailed statistical analysis plan. Acta Anaesthesiol Scand. 2017;61(7):859-68.

40. Jörg Schefold et al: Sup-Icu RENal (SIREN) - a Sub-analysis of the Prospective SUP (Stress Ulcer Prophylaxis)-ICU Trial on the Risk of GI- Bleeding in ICU Patients Receiving Renal Replacement Therapy. https://clinicaltrials.gov/ct2/ show/NCT02718261?term $=02467621 \&$ recrs $=a b \& r a n k=1$. Accessed 10 Jan 2018

Submit your next manuscript to BioMed Central and we will help you at every step:

- We accept pre-submission inquiries

- Our selector tool helps you to find the most relevant journal

- We provide round the clock customer support

- Convenient online submission

- Thorough peer review

- Inclusion in PubMed and all major indexing services

- Maximum visibility for your research

Submit your manuscript at www.biomedcentral.com/submit 